EISSN: $2706-7947 \quad$ ISSN: 2077- 4613

DOI: $10.36632 /$ mejas/2021.11.1.28

Journal homepage: www.curresweb.com

Pages: 343-359

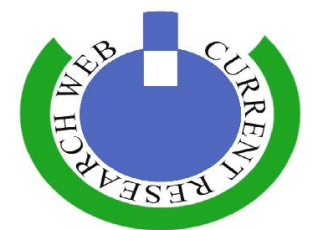

\title{
Productivity and Pest Resistance of Black Cumin in Response to Organic and Chemical Fertilizers
}

Esam A. A. Al-Azzony ${ }^{1}$ and M.M.A. Ibrahim ${ }^{2}$

${ }^{1}$ Medicinal and Aromatic Plants Research Department, Horticulture Research Institute, ARC, Egypt. ${ }^{2}$ Piercing-Sucking Insect Research Department, Plant Protection Research Institute, ARC, Egypt.

Received: 27 January $2021 \quad$ Accepted: 25 March $2021 \quad$ Published: 30 March 2021

\begin{abstract}
The present study was carried out to investigate the impact of organic fertilizers as land application under NPK levels on black cumin (Nigella sativa L.) growth, chemical components, productivity, susceptibility to pest's infestation and harboring natural enemies during 2016 / 2017 and 2017 / 2018 seasons. The results cleared that, the tested fertilizers were influenced target parameters of $N$. sativa plants significantly. The high means of plant height, root length, branches, roots and inflorescences numbers, fresh weight of plant (with and without fruit), fruit, root and 100 seeds; chemical components of, N, P, K, Carbohydrates, Volatile oil and Fixed oil; Also, the high values of Lauric, Myristi, Palmitic, Stearic, Oleic, Linoleic, Linolenic and Eicosadienoic fatty acids were recorded for plants received humic acid and/or Nitrobeen under the level of $75 \%$ NPK. The results of pests infested $N$. sativa plants revealed highly significant differences $(\mathrm{P} \leq 0.01)$ between its mean numbers due to variation in rates and types of fertilizers. The lowest mean numbers of dominant pests were recorded for $E$. decipiens, $A$. gossypii, B. tabaci and T. tabaci, N.viridula, O. hyalinipenni and H. armigera on N. sativa plants received same previous treatments. Also, the mean numbers of inspected pests were correlated significantly with plant height and branches number. According to these results, mineral fertilizers could be managed with bio and organic fertilizers for producing good yield and tolerant black cumin plants to pest's infestation to avoid bad side effects of agrochemicals with the aim to get safe foods
\end{abstract}

Keywords: black cumin, bio fertilizer, humic acid, growth characters, chemical composition, pest resistance

\section{Introduction}

The genus Nigella belongs to the family Ranunculaceae includes of 14 species of annual herbs, native to the Mediterranean region (Davis, 1965). In Egypt $N$. sativa crop is one of the most promising medicinal plant; widely cultivated in middle and upper Egypt regions, for seed yield and oil production. The whole seeds contain $30-35 \%$ of oil (fixed and volatile) which uses in pharmaceutical and food industries (Ustun et al., 1990). N. sativa plants was cultivated especially for the important commercial plant part which is seeds used as a spice and in folk (herbal) medicine all over the world for the treatment and prevention of a number of diseases (Leung and Foster, 1996; Badary, 1999); Dwivedi et al., 2007).

The excessive use of chemical fertilizers revealed serious environmental effects especially by contamination of water bodies as well as groundwater and residues in treated plants, which impacts the public health, environment, increasing production cost, sensitivity of plants to pests and diseases Chen, 2006 and Boraste et al., 2009. So, the researchers consider the utilization of organic, bio fertilizers as promising alternative nutrition and bio pesticides to grow crops to reduce pollution practices in sustainable agriculture especially for developing countries. The use of organic materials fertilization improves physical, chemical, biological soil proprieties, water retention ability, and cations exchange capacity. Also, converting nitrogen into a less soluble form compared to chemical fertilizers and found influenced N. sativa plants growth and production, Gyaneshwar, et al., ( 2002) and Haj Seyed Hadi et al., (2011) Mohammad et al (2013).

Corresponding Author: Esam A.A. Al-Azzony, Medicinal and Aromatic Plants Research Department, Horticulture Research Institute, ARC, Egypt. 
The vegetative growth, fruit as well as oil yields of $N$. sativa were enhanced by using organic manure (Abdou and Mohamed 2003; Hassan and Ali 2013). Moreover, the photosynthetic pigments and carbohydrates percentage and NPK contents were also enhanced (Fernandes et. al., 2002; Abdou and Mohamed 2003). On the other hand, cattle manure application has been found to reduce nitrate and nitrite contents in seeds (Singh 2004; Zhou and Luo 2004; Hassan and Ali 2013). The oil content and its main components were also affected by cattle manure in different crops (Jhaa et al., 2011; Hassan and Ali 2013).

The use of nitrogen fixation and phosphate solubilization bacteria in the rhizosphere, becomes necessary to minimize the chemical fertilizer doses of that cause environmental pollution and for its ability to synthesize antibiotics and growth promoting substances including phytohormones (Gendy et al., 2012; Hassan et al., 2012). Also, The mixed treatment of nitrogen fixation and phosphate solubilization bacteria resulted in the maximum increase in growth and yield parameters of several medicinal and aromatic plants (Chen 2006; Helal et al., 2011; Akhani et al., 2012; Sokhangoy et al., 2012; Hassan et al., 2012; Hassan and Ali 2013). The essential oil content and its main components of various Apiaceae fruits were increased by using organic and bio fertilizers ( cattle manure (CM), phosphorein, and Halex-2 combination). In addition, carbohydrate percentage as well as NPK content in leaves were also promoted (Hassan et al., 2012; Dadkhah 2012; Hassan and Ali 2013). The combination of organic and bio fertilizers proved to be the superior treatment, compared to the individual application, which reflected in the greatest influence on growth, yield, oil content and chemical constituents of marjoram, N. sativa and H. sabdariffa plants (Al-Fraihat et al., 2011; Shaalan 2005; Gendy et al., 2012; Valadabadi and Farahani 2013)..The beneficial effect of bio-N-fertilizers application is the improvement of nitrogen contents, as well as the improvement of the physical and chemical properties of the yield, those such as: biological yield, seed, essential oil yield, stem dry weight, capsule dry weight, leaf dry weight and plant height were higher in unites by 20 ton/ha animal manure and Azotobacter application (Sayed and Hossein, 2011). Also, Fernandes et al., (2002); Abdou and Mohamed ( 2003); Katkat et al., 2009 and Khalid and Shedeed (2015) mentioned that the photosynthetic pigments and carbohydrates percentage and NP K contents were also enhanced by using of bio and organic fertilizers, Shaalan (2005) Jhaa et al., (2011); Hassan and Ali (2013) recorded that the oil content and its main components were also affected by organic fertilizers in different crops. In addition to that, Ali and Hassan(2014) mentioned that the volatile and fixed oil contents and their main components were also enhanced by using cattle manure, bio fertilizers and their combinations on $N$ sativa plants.

The $N$. sativa plants are usually attacked with many pests throughout vegetative and fruiting periods that lead to great losses in yield quality and quantity of these plants. The piercing-sucking pests (Aphid's species, leafhoppers, whiteflies, thrips, stink bugs and mites) cotton seeds bug and tomato fruit worm are the most destructive insects on these plants. Abd El-Moniem and Abd El-Wahab, 2006; Bhagat, 2012; Abd El-Wahab, et al., 2011 and Elekcioğlu (2020). The piercing sucking insects not only deprive host plant of important metabolites but also vector viral diseases in the same (Hooks and Fereres, 2006; Rasmussen et al., 2008; Catangui et al., 2009). El-Kordy (1999) studied population dynamics of aphids infesting medicinal and aromatic plants in Egypt. Bhagat (2012) reported 63 aphid species damaging 92 medicinal plants in India. The aphids infestation and pest- managerial, carried out in Pakistan mainly have been food crops biased (Ali and Aheer, 2007; Amer et al., 2009 Akhtar et al., 2010; Hassan et al., 2010; Bodlah et al., 2011; Akmal et al., 2013). Also, beneficial insects such as predators, parasitoids, pollinators and visitors could play an important role in improvement the productivity of $N$. sativa plants. A number of investigations have been surveyed the insects inhabiting different medicinal plants. Abdel-Moniem and Abdel-Wahab, 2006). Abd El-Wahab, et al., 2011, in Egypt stated that the N. sativa found infested with Thrips tabaci (Lind.) Oxycarinus hyalinipennis, Emposca descipiens (Padi.) Aphis gossypii (Clova.) Aphis crassivora (Koch.) and associated with certain bio enemies as Syrphus corolla F. Chrysopa vulgaris (Schn) Aphilinus sp. Coccinella undecimpunctata. As our knowledge, few studies have been conducted so far to study the effect of organic fertilizers and interactive effect of bio and NPK fertilizers on N. sativa plants. Moreover, improving not only the quantity but also the quality of black cumin yield was and still the main goal of several investigators.

So, the aim of this study was to evaluate the impact of bio and organic fertilizers their interactions with NPK levels on the growth, yield and oil content and its composition of black cumin plant as well 
as pests infestation and their associated natural enemies to reveal the suitable treatment which protect and maximizing seeds, oils yield and obtaining the highest quality product.

\section{Materials and Methods}

The present study was carried out in the Experimental Farm, Faculty of Agriculture, Suez Canal University, at El Ismailia, Egypt, to investigate the impact of organic, bio fertilizers under certain mineral NPK levels on $N$. sativa growth, seed yield, oil production, chemical constituents, pests infestation and associated natural enemies during two successive seasons of 2016 / 2017 and 2017 / 2018.

The experiment area about $1008 \mathrm{~m}^{2}$ was divided to plots each $21 \mathrm{~m}^{2}$ arranged as a complete randomized block design as 16 treatments each with three replicates. The seeds of black cumin (obtained from Medicinal and Aromatic Plants Department, Horticulture Research Institute, Agriculture Research Center, Giza, Egypt) were sown in sandy soil at distance of $30 \mathrm{~cm}$ in the experimental units on the $1^{\text {st }}$ week of November, during the two study seasons. The thinning was done after six weeks from planting (two seedlings per hill).

The treatments were:

$100 \%$ NPK only, $100 \%$ NPK + humic, $100 \%$ NPK + bio fertilizer, $100 \%$ NPK + bio fertilizer + humic; $75 \%$ NPK only, $75 \%$ NPK + humic, $75 \%$ NPK + bio fertilizer, $75 \%$ NPK + bio fertilizer + humic; $50 \%$ NPK only, $50 \%$ NPK +humic, $50 \%$ NPK + bio fertilizer, $50 \%$ NPK + bio fertilizer + humic; $25 \%$ NPK only, 25\% NPK + humic, 25\% NPK + bio fertilizer, and $25 \%$ NPK + bio fertilizer + humic.

The bio fertilizer (Nitrobeen, containing N- fixing bacteria Azospirillum brasilene $(2.1 \times 109$ cell $/ \mathrm{cm} 3$ ) used at rate of $500 \mathrm{~g} / \mathrm{kg} \mathrm{N}$. sativa seeds. The plants were chemically fertilized by ammonium sulphate $(20.5 \mathrm{~N} \%)$, calcium superphosphate (15.5 P2O5\%) and potassium sulphate (48 K2O \%). The $\mathrm{N}$ and $\mathrm{P}$ fertilizers were applied as soil dressing beside drippers. The amount of $\mathrm{N}$ and $\mathrm{P}$ fertilizers were divided into three equal doses, the first dose was added after one month from planting, whereas the other two doses were applied 20 days between them and between the first one. While calcium super phosphate fertilizer was added during soil preparation.

Preparation of humic acid was from, vegetarian humic acid fertilizer which contains $86 \%$ humic acid (Abo-Zaabal Company for Fertilizers Manufacturing). Humic acid fertilizer was added to the experimental units (soil adding) as a rate of $280 \mathrm{~g} / \mathrm{fed}$., one month from planting and repeated one month later.

\subsection{Data recorded:}

2.1.1. Vegetative growth: Plant height $(\mathrm{cm})$, Branches numbers, Root Length $(\mathrm{cm})$, Roots number and Inflorescences numbers, Fresh weight of total plant (g.), Fresh weight of plant without fruits (g), Fresh weight of fruits (g.), Fresh weight of root (g.), Inflorescences fresh weight (g.), Weight of 100 seeds (g).

2.1.2. Chemical composition: Nitrogen $\%$, phosphorus $\%$, potassium $\%$, Volatile oil $\%$, Fixed oil $\%$, and Carbohydrates contents, Fatty acids content: Lauric, Myristic, Palmitic, Stearic, Oleic, Linoleic, Linolenic, Eicosadienoic.

\subsection{Chemical analysis}

Essential oil percentage was determined in the seeds of black cumin using $100 \mathrm{~g}$ crushed (just before distillation). Volatile oil in the seeds was extracted by water distillation according to Egyptian Pharmacopoeia (1961). Distillation was continued for three hours after boiling to complete the oil extraction. The oil was then left to stand un-disturbed to assure complete separation and determined according to Guenther (1961). The volatile oil percentage was calculated as $\mathrm{ml}$ of oil per $100 \mathrm{~g}$ of dried seeds.

Fixed oil percentages, estimated by Sox let apparatus using petroleum ether $\left(40-60 \mathrm{C}^{\circ}\right)$ as a solvent according to Association of Official Agricultural Chemists A.O.A.C, 1990.

Determination of carbohydrates (Hansen and Moller 1975)

Nutrient contents: N (Black et al., 1965), P and K (Jackson (1978)) percentage in leaves. 


\subsection{Insects, mite pests and associated natural enemies sampling}

In this study two sampling techniques were applied to survey and estimate population densities of pests and associated natural enemies on black cumin plants.

2.3.1. The first was plant samples technique: weekly sample of ten seedlings (at seedling stage) or ten leaves of mature plants in each of the three replicates plot were selected randomly from different plants canopy levels and inspected actually early in the morning in the field using hand lens (10x), to count all stages of pests individuals (mean numbers/leaf). The mean numbers of stink green bug and natural enemies (except mite predators which counted on leaves with phytophagous mite) were estimated based on the branches (number/plant).

2.3.2. The second was sweeping net technique: sweeping net (with a diameter of $30 \mathrm{~cm}$ and $70 \mathrm{~cm}$ in depth) was used to provide true indicator about flight insects especially leafhoppers, weekly 5 strokes were took from each plot; the caught insects species were transferred to plastic sacks, tied by rubber bands and taken to the laboratory for identification, counting and recording. The sampling operation was started just after emergence complete and continued till harvest. In case of each of cotton seed bug and tomato fruit worms, samples of 20 fruit /replicate were examined in randomized and inspected throughout the flowering and fruiting period.

\subsection{Statistical analysis:}

The data were statistically analyzed using one-way analysis of variance (ANOVA) and the values of least significant difference (LSD) at 5\% according to Little and Hills (1975).

\section{Results and discussion}

\subsection{Growth characters}

The obtained data in Table (1) show that, the organic and bio fertilizers positively affected plants height, roots length, branches \& roots and Inflorescences numbers under different levels of NPK fertilizer. The relatively highest means of $41 \mathrm{~cm} /$ plant, $15.5 \mathrm{~cm}$ length, 17.00 branches/plant, 9.5 root /plant and 26.5 inflorescences /plant were recorded for plants received Nitrobeen and/or humic acid under the level of $75 \%$ NPK during the two study seasons. On the other hand, the lowest growth characters means of $19.5 \mathrm{~cm}$ plant height (plants received Nitrobeen only under treatment of $100 \%$ NPK level.) , 4.5 branches/plant (plants received humic and Nitrobeen under $100 \%$ NPK level), $5.5 \mathrm{~cm}$ root length (plants received humic under $100 \%$ NPK level), 3.00 root/plant and 8 inflorescences/ plant (plants received $25 \%$ NPK only).

Generally, the results of statistical analysis showed highly significant differences between growth characters means of $N$. sativa plants fertilized by organic and bio fertilizers under different levels of NPK fertilization. The relatively highest means of growth characters were recorded for plants received Nitrobeen (bio fertilizer) and/or humic acid (organic fertilizer) under the level of $75 \%$ NPK. The present results found in agreement with those of (Abdou and Mohamed 2003; Hassan and Ali 2013) who reported that the vegetative growth, fruit were enhanced by using organic fertilizers. Also, that of Abou El-Leel et al., (2019) who indicated that the application of biogein (biofertilizer) and humic acid stimulated vegetative growth of $N$. sativa, whereas, data showed a significant increase in plant height and number of branches/plant compared to untreated plants ; Aiyafar et al., (2015) who stated that the application of humic acid increased its plant height, capsule and leaves number per plant . in the same trend the results of Mousa et al., (2012) mentioned that the use of organic and NPK fertilizers, significantly increased plant height, branch number per plant, than other treatments.

In regarding to the fresh weight of plants and plant parts, the obtained results in table (2) show that the organic (Humic acid) and bio (Nitrobeen )fertilizers at different NPK fertilizer levels were positively influenced the fresh weight of total plant with and without fruits, fruits, roots, inflorescences and seeds weight $N$. sativa plants. The mean values of affected variables were varied significantly as treatments variation and the relatively highest mean of $45.3(\mathrm{~g}) / \mathrm{plant}$, fresh weight, $19.2(\mathrm{~g}) / \mathrm{plant}$ without fruits, of $26.55(\mathrm{~g}) /$ fruit $1.95 \mathrm{~g} /$ root, $24.65(\mathrm{~g}) /$ inflorescences and $0.039(\mathrm{~g}) / 100$ seeds were recorded for plants received Nitrobeen and/or Humic acid under treatment of $75 \%$ NPK during the two 
Middle East J. Appl. Sci., 11(1): 343-359, 2021

EISSN: $2706-7947$ ISSN: 2077-4613

Table 1: Effect of bio and organic fertilizers under different levels of chemical fertilization on vegetative growth characters on $N$. sativa plants during the two seasons of 2016/2017 and 2017/2018.

\begin{tabular}{|c|c|c|c|c|c|c|c|c|c|c|}
\hline \multirow{2}{*}{ Treatments } & \multicolumn{2}{|c|}{ Plant height (cm) } & \multicolumn{2}{|c|}{ Branches No. } & \multicolumn{2}{|c|}{ Root length (cm) } & \multicolumn{2}{|c|}{$\begin{array}{c}\text { Roots } \\
\text { No. }\end{array}$} & \multicolumn{2}{|c|}{ Inflorescences No } \\
\hline & S1 & $\mathbf{S 2}$ & S1 & S2 & S1 & S2 & S1 & S2 & S1 & $\mathbf{S 2}$ \\
\hline $100 \%$ NPK & 23.50 & 27.00 & 6.50 & 8.00 & 12.50 & 15.00 & 5.00 & 6.00 & 18.00 & 14.00 \\
\hline $100 \%$ NPK +humic acid & 34.00 & 27.50 & 6.50 & 7.50 & 8.50 & 5.50 & 6.50 & 4.00 & 19.50 & 18.00 \\
\hline $100 \%$ NPK + bio fertilizer & 23.25 & 19.50 & 7.50 & 5.00 & 11.10 & 11.75 & 4.50 & 5.00 & 23.00 & 10.00 \\
\hline $100 \%$ NPK + bio fertilizer + humic acid & 30.00 & 32.5 & 7.50 & 4.50 & 11.00 & 6.00 & 5.50 & 5.00 & 19.50 & 11.50 \\
\hline $75 \%$ NPK & 35.50 & 29.00 & 6.50 & 5.00 & 10.50 & 11.00 & 8.50 & 7.00 & 13.50 & 13.00 \\
\hline $75 \%$ NPK +humic acid & 36.00 & 35.00 & 12.00 & 17.00 & 11.00 & 13.50 & 6.50 & 9.00 & 11.50 & 24.50 \\
\hline $75 \%$ NPK + bio fertilizer & 34.50 & 37.00 & 8.00 & 17.00 & 15.00 & 15.50 & 9.00 & 8.50 & 18.50 & 26.50 \\
\hline $75 \%$ NPK + bio fertilizer + humic acid & 41.00 & 39.50 & 10.50 & 8.50 & 13.00 & 13.50 & 9.00 & 8.00 & 25.50 & 13.00 \\
\hline $50 \%$ NPK & 30.50 & 39.00 & 6.50 & 9.00 & 10.50 & 13.00 & 4.50 & 6.50 & 9.00 & 12.00 \\
\hline $50 \%$ NPK +humic acid & 37.00 & 29.50 & 7.00 & 12.50 & 13.00 & 10.50 & 4.50 & 8.00 & 14.00 & 22.50 \\
\hline $50 \%$ NPK + bio fertilizer & 26.00 & 25.50 & 12.00 & 9.00 & 6.00 & 7.00 & 4.00 & 3.50 & 17.00 & 23.00 \\
\hline $50 \%$ NPK + bio fertilizer + humic acid & 26.00 & 33.00 & 9.00 & 11.50 & 13.00 & 12.50 & 6.50 & 9.50 & 11.00 & 20.50 \\
\hline $25 \%$ NPK & 25.50 & 24.50 & 10.00 & 5.00 & 13.00 & 8.50 & 5.00 & 3.00 & 21.50 & 8.00 \\
\hline $25 \%$ NPK +humic & 26.00 & 33.50 & 8.00 & 10.50 & 10.00 & 12.00 & 6.00 & 9.00 & 13.00 & 22.00 \\
\hline $25 \%$ NPK + bio fertilizer & 25.50 & 30.08 & 5.50 & 8.58 & 9.50 & 9.33 & 4.66 & 5.00 & 10.66 & 17.33 \\
\hline $25 \%$ NPK + bio fertilizer + humic acid & 27.00 & 28.00 & 11.00 & 6.00 & 10.50 & 11.00 & 4.50 & 3.50 & 18.00 & 16.00 \\
\hline F values & 7.455 & 8.103 & 4.229 & 4.229 & 4.657 & 10.660 & 5.230 & 4.840 & 3.710 & 4.835 \\
\hline LSD $_{0.05}$ & 5.829 & 5.528 & 2.954 & 4.158 & 2.789 & 2.667 & 2.103 & 2.888 & 7.202 & 7.398 \\
\hline
\end{tabular}


Table 2: Effect of some bio and organic fertilizers under different levels of chemical fertilization on fresh weight of plant parts and seed yield of $N$. sativa plants during the two seasons of 2016/2017 and 2017/2018.

\begin{tabular}{|c|c|c|c|c|c|c|c|c|c|c|c|c|}
\hline \multirow[t]{2}{*}{ Treatments } & \multicolumn{2}{|c|}{$\begin{array}{l}\text { Total plant fw. } \\
\text { (g) }\end{array}$} & \multicolumn{2}{|c|}{$\begin{array}{l}\text { Total without } \\
\text { fruits fw.(g) }\end{array}$} & \multicolumn{2}{|c|}{$\begin{array}{l}\text { Fruits fw. } \\
\text { g }\end{array}$} & \multicolumn{2}{|c|}{$\begin{array}{c}\text { Root fw. } \\
(\mathrm{g})\end{array}$} & \multicolumn{2}{|c|}{$\begin{array}{c}\text { Inflore } \\
\text { fw (g) }\end{array}$} & \multicolumn{2}{|c|}{$\begin{array}{l}\text { weight } 100 \text { seeds } \\
(\mathrm{g})\end{array}$} \\
\hline & S1 & S2 & S1 & S2 & S1 & S2 & S1 & S2 & S1 & S2 & S1 & S2 \\
\hline $100 \%$ NPK & 25.45 & 21.35 & 12.90 & 10.25 & 12.55 & 4.10 & 1.1 & 1.1 & 14.10 & 10.05 & 0.0363 & 0.030 \\
\hline $100 \%$ NPK +humic acid & 32.05 & 20.10 & 16.35 & 15.25 & 15.70 & 4.85 & 1.90 & 1.05 & 16.10 & 10.05 & 0.0347 & 0.033 \\
\hline $100 \%$ NPK + bio fertilizer & 13.60 & 12.10 & 9.25 & 4.65 & 4.35 & 7.45 & 0.95 & 0.70 & 10.80 & 6.10 & 0.0337 & 0.030 \\
\hline $\begin{array}{l}100 \% \mathrm{NPK}+\text { bio fertilizer + humic } \\
\text { acid }\end{array}$ & 29.45 & 14.65 & 15.45 & 6.60 & 14.00 & 8.05 & 0.95 & 0.60 & 13.10 & 7.50 & 0.0207 & 0.024 \\
\hline $75 \%$ NPK & 21.90 & 15.50 & 11.20 & 7.38 & 10.70 & 8.12 & 0.85 & 0.90 & 9.15 & 7.00 & 0.0333 & 0.025 \\
\hline $75 \%$ NPK +humic acid & 19.30 & 32.85 & 8.93 & 15.40 & 10.33 & 17.45 & 0.75 & 1.40 & 8.85 & 15.40 & 0.0187 & 0.022 \\
\hline $75 \%$ NPK + bio fertilizer & 27.00 & 45.30 & 11.75 & 18.75 & 15.25 & 26.55 & 0.90 & 1.75 & 13.61 & 24.65 & 0.027 & 0.033 \\
\hline $75 \%$ NPK + bio fertilizer + humic acid & 40.85 & 21.90 & 19.20 & 10.35 & 21.65 & 11.55 & 1.95 & 1.35 & 18.91 & 9.98 & 0.037 & 0.031 \\
\hline $50 \%$ NPK & 9.60 & 15.10 & 3.80 & 5.70 & 5.80 & 9.40 & 0.45 & 0.70 & 5.10 & 7.85 & 0.027 & 0.032 \\
\hline $50 \%$ NPK +humic acid & 17.75 & 23.10 & 7.90 & 10.80 & 9.85 & 12.30 & 1.25 & 1.20 & 8.35 & 11.00 & 0.036 & 0.039 \\
\hline $50 \%$ NPK + bio fertilizer & 16.35 & 19.85 & 7.40 & 8.40 & 8.95 & 11.45 & 0.50 & 0.45 & 8.20 & 11.45 & 0.025 & 0.033 \\
\hline $50 \%$ NPK + bio fertilizer + humic acid & 13.55 & 29.85 & 6.60 & 14.55 & 6.95 & 15.30 & 0.50 & 1.95 & 6.90 & 12.55 & 0.0303 & 0.032 \\
\hline $25 \%$ NPK & 19.10 & 8.65 & 7.65 & 3.80 & 11.45 & 4.85 & 0.75 & 0.45 & 10.30 & 4.45 & 0.0313 & 0.037 \\
\hline $25 \%$ NPK +humic & 15.10 & 25.15 & 7.05 & 12.15 & 8.05 & 13.00 & 0.65 & 1.10 & 7.10 & 10.85 & 0.036 & 0.037 \\
\hline $25 \%$ NPK + bio fertilizer & 10.56 & 17.30 & 4.42 & 8.52 & 6.14 & 8.78 & 0.56 & 0.43 & 5.56 & 7.81 & 0.036 & 0.033 \\
\hline $25 \%$ NPK + bio fertilizer + humic acid & 21.55 & 11.50 & 11.60 & 7.05 & 9.95 & 4.00 & 0.55 & 0.25 & 8.95 & 6.25 & 0.0373 & 0.037 \\
\hline F values & 4.229 & 4.229 & 3.215 & 3.850 & 3.850 & 6.380 & 6.289 & 3.579 & 3.881 & 6.400 & 2.484 & 3.441 \\
\hline LSD $_{0.05}$ & 11.0147 & 11.818 & 6.918 & 6.307 & 6.307 & 6.381 & 0.525 & 0.748 & 5.675 & 5.394 & 0.0736 & 0.0079 \\
\hline
\end{tabular}

$\mathbf{S 1} *=1^{\text {st }}$ season and $\mathbf{S 2} * *=2^{\text {nd }}$ season 
Table 3: Effect of some bio and organic fertilizers under different levels of chemical fertilization on nitrogen, phosphorus, potassium, Volatile oil\% Fixed oil $\%$ and Crrbohydrates contents in N. sativa plants during the two seasons of 2016/2017 and 2017/2018.

\begin{tabular}{|c|c|c|c|c|c|c|c|c|c|c|c|c|}
\hline \multirow{2}{*}{ Treatments } & \multicolumn{2}{|c|}{$\mathbf{N} \%$} & \multicolumn{2}{|c|}{$\mathbf{P} \%$} & \multicolumn{2}{|c|}{$K \%$} & \multicolumn{2}{|c|}{ Carbohydrates } & \multicolumn{2}{|c|}{ Volatile oil\% } & \multicolumn{2}{|c|}{ Fixed oil \% } \\
\hline & S1 & S2 & S1 & S2 & S1 & S2 & S1 & S2 & S1 & S2 & S1 & S2 \\
\hline $100 \%$ NPK & 2.84 & 2.74 & 0.291 & 0.282 & 2.16 & 2.06 & 21.2 & 20.6 & 0.220 & 0.222 & 30.8 & 29.6 \\
\hline $\begin{array}{l}100 \% \text { NPK +humic } \\
\text { acid }\end{array}$ & 2.99 & 2.86 & 0.308 & 0.298 & 2.21 & 2.15 & 22.8 & 21.2 & 0.232 & 0.231 & 31.4 & 29.2 \\
\hline $\begin{array}{l}100 \% \text { NPK + bio } \\
\text { fertilizer }\end{array}$ & 2.76 & 2.63 & 0.278 & 0.278 & 2.06 & 1.98 & 21.4 & 20.0 & 0.208 & 0.212 & 30.8 & 29.2 \\
\hline $\begin{array}{l}100 \% \text { NPK + bio } \\
\text { fertilizer + humic acid }\end{array}$ & 3.08 & 2.98 & 0.325 & 0.316 & 2.36 & 2.26 & 23.6 & 21.8 & 0.249 & 0.238 & 32.2 & 30.6 \\
\hline $75 \%$ NPK & 3.12 & 2.99 & 0.341 & 0.329 & 2.37 & 2.44 & 23.2 & 22.6 & 0.266 & 0.268 & 34.1 & 32.2 \\
\hline $75 \%$ NPK +humic acid & 3.24 & 3.28 & 0.362 & 0.348 & 2.42 & 2.52 & 24.6 & 22.4 & 0.273 & 0.282 & 35.9 & 33.0 \\
\hline $\begin{array}{l}75 \% \text { NPK + bio } \\
\text { fertilizer }\end{array}$ & 3.15 & 3.08 & 0.335 & 0.331 & 2.39 & 2.38 & 23.2 & 21.2 & 0.274 & 0.274 & 32.8 & 31.0 \\
\hline $\begin{array}{l}\text { 75\% NPK + bio } \\
\text { fertilizer + humic acid }\end{array}$ & 3.31 & 3.36 & 0.396 & 0.364 & 2.51 & 2.68 & 25.4 & 23.6 & 0.285 & 0.296 & 36.6 & 34.2 \\
\hline $50 \%$ NPK & 2.69 & 2.75 & 0.242 & 0.253 & 1.89 & 2.02 & 19.6 & 20.8 & 0.185 & 0.198 & 27.9 & 27.4 \\
\hline $50 \%$ NPK +humic acid & 2.71 & 2.86 & 0.251 & 0.267 & 2.02 & 2.14 & 20.2 & 20.6 & 0.192 & 0.186 & 27.9 & 28.2 \\
\hline $\begin{array}{l}50 \% \text { NPK + bio } \\
\text { fertilizer }\end{array}$ & 2.59 & 2.68 & 0.239 & 0.245 & 1.92 & 2.09 & 18.8 & 19.8 & 0.177 & 0.174 & 26.4 & 27.6 \\
\hline $\begin{array}{l}50 \% \text { NPK + bio } \\
\text { fertilizer + humic acid }\end{array}$ & 2.82 & 2.98 & 0.265 & 0.278 & 2.11 & 2.28 & 21.4 & 21.4 & 0.210 & 0.215 & 29.5 & 29.6 \\
\hline $25 \%$ NPK & 2.47 & 2.39 & 0.202 & 0.209 & 1.82 & 1.78 & 17.6 & 17.8 & 0.159 & 0.162 & 24.5 & 26.8 \\
\hline $25 \%$ NPK +humic & 2.52 & 2.5 & 0.212 & 0.206 & 1.79 & 1.92 & 18.2 & 17.4 & 0.171 & 0.176 & 25.9 & 26.2 \\
\hline $\begin{array}{l}25 \% \text { NPK + bio } \\
\text { fertilizer }\end{array}$ & 2.32 & 2.41 & 0.189 & 0.195 & 1.68 & 1.84 & 15.8 & 16.2 & 0.148 & 0.156 & 24.2 & 27.0 \\
\hline $\begin{array}{l}25 \% \text { NPK + bio } \\
\text { fertilizer + humic acid }\end{array}$ & 2.61 & 2.66 & 0.221 & 0.226 & 1.88 & 2.05 & 18.4 & 18.8 & 0.180 & 0.196 & 27.1 & 28.2 \\
\hline F values & 6953.4 & 3.8496 & 10840 & 3.7966 & 2.5485 & 5.9891 & 30.127 & 27.445 & 3.3535 & 387.47 & 70.485 & 6.6701 \\
\hline LSD $_{0.05}$ & 0.0102 & 1.3143 & 5.3678 & 2.4414 & 4.6467 & 9.2935 & 1.4403 & 1.1000 & 6.9809 & 0.0083 & 1.2473 & 8.1491 \\
\hline
\end{tabular}

$\mathbf{S 1} *=1^{\text {st }}$ season and $\mathbf{S} 2 * *=2^{\text {nd }}$ season 
study seasons. In contrary, the relatively lowest mean numbers of $8.65(\mathrm{~g}) / \mathrm{plant} 3.8 \mathrm{~g} /$ plant without fruits, $4.25(\mathrm{~g}) /$ fruit, $0.25(\mathrm{~g}) /$ root, $4.45(\mathrm{~g}) /$ inflorescences and $0.0207 \mathrm{~g} / 100$ seeds were recorded for plants that received $25 \%$ and or $50 \%$ NPK without bio and organic fertilizers.

Generally, the relatively high values of fresh weight of plants and plant parts were recorded for plants fertilized by bio and organic fertilizers or with any of its at $75 \%$ and/or $50 \%$ NPK levels. The present results show in agree of those of (Katkat et al., 2009) who stated that the use of bio fertilizers and humic acid was positively affected plant height and grain yield. Also, that of Shaalan (2005) who noted that the plant height, number of branches, and seed yield per $N$. sativa plant was increased with Biogein, Nitrobeen and Phosphorein either individually or in combination use. In the same trend, that of Al-Fraihat et al., (2011); Shaalan (2005); Gendy et al., (2012); Valadabadi and Farahani (2013) who reported that the combination of organic and bio fertilizers proved to be the superior treatment, compared to the individual application, which reflected in the greatest influence on growth and yield of different medicinal and aromatic plants. In addition that of Ali et al., (2015) who mentioned that the plant weight, plant branch, fruit plant, seed capsule and grain yield of black cumin were significantly influenced by different levels of NPK fertilizers.

\subsection{Chemical composition}

The tabulated data in Table (3) cleared the effects of different combination between organic, bio and NPK fertilizers treatments, on chemical components percentages of $N$. sativa plants. The data cleared that, the highest levels of nitrogen, phosphorus, potassium, Carbohydrates, Volatile oil $\%$ and Fixed oil \% of 3.36, 0.396, 2.68, 25.4, $0.296 \%$ and $36.6 \%$ were recorded for these components in plants treated with Nitrobeen and humic under treatment of $75 \%$ NPK during the two study seasons, respectively. In contrary, the relatively low values of the estimated components were $2.32,0.195,1.68$, $15.8,0.148 \%$ and $24.2 \%$ obtained from plants received Nitrobeen only under $25 \%$ NPK level treatment, respectively. These results showed in harmony of those of Fernandes et al. (2002); Abdou and Mohamed (2003) who mentioned that the carbohydrates percentage and N, P and K contents were also enhanced by using of bio and organic fertilizers, also that of Shaalan (2005) Jhaa et al., (2011); Hassan and Ali (2013) who recorded that the oil content and its main components were also affected by organic fertilizers in different crops.

In addition to that of Ali and Hassan(2014) who get that the volatile and fixed oils content and its main components were also enhanced by using cattle manure bio fertilizer and their combinations on Nigella sativa L. plants .In the same trend, the relatively highest determined values of fatty acids were found in plants fertilized by Nitrobeen and humic under treatment of $75 \%$ NPK during the two study seasons recording values of $0.70,1.51,13.02,3.42,23.62,53.66,0.73$ and 3.12 for Lauric, Myristi, Palmitic, Stearic, Oleic, Linoleic, Linolenic and Eicosadienoic fatty acids, respectively. Also, the lowest values of $0.51,0.80,11.76,2.54,21.06,47.06,0.48$ and 1.98 were noticed for estimated fatty acids in plants received $25 \%$ NPK only or with adding bio fertilizer during the $1^{\text {st }}$ season respectively.

That mean the use of humic play an important role in increasing of chemical constituents levels when used with bio fertilizer under different NPK levels especially that of $75 \%$ NPK. These results show in harmony of those of Chen 2006; Helal et al., 2011; Akhani et al., 2012; Sokhangoy et al., 2012; Hassan et al., 2012; Hassan and Ali 2013) who stated that The mixed treatment of nitrogen fixing bacteria and phosphate solublizing bacteria resulted in the maximum increase in most of the growth and yield parameters of several medicinal and aromatic plants.

\subsection{The pests infested $N$. sativa plants and its associated insect predators 3.3.1. Pests survey}

The results in Table (4) reveal that, the main and dominant pests attacked $N$. sativa presented in relatively high numbers were; potato leafhopper, Emposca descipiens (Paol.); cotton aphids, Aphis gossypii (Glov.); cotton whitefly, Bemisia tabaci (Genn.); onion thrips, Thrips tabaci (Lind.); the two spotted spider mite Tetranychus urticea (Koch). In addition to the three insect pests found infested $N$. sativa throughout flowering and fruiting periods; green stink bug, Nezara viridula L. and Oxycarenus hyalinipennis (Costa). Also, the tomato fruit worm, Helicoverpa armigera (Hübner). On the other hand, the green peach aphids, Myzus persicae (Sulz); cow bean aphids, Aphis craccivora; Hyadaphis foeniculi (Passerini) and Flower thrips , Frankliniella occidentalis (Pergande) were occurred on N. sativa in very low numbers 
Table 4: Effect of some bio and organic fertilizers under different levels of chemical fertilization on Fatty acids components in $N$. sativa plants during the two seasons of 2016/2017 and 2017/2018.

\begin{tabular}{|c|c|c|c|c|c|c|c|c|c|c|c|c|c|c|c|c|}
\hline \multirow{2}{*}{ Treatments } & \multicolumn{2}{|c|}{ Lauric } & \multicolumn{2}{|c|}{ Myristic } & \multicolumn{2}{|c|}{ Palmitic } & \multicolumn{2}{|c|}{ Stearic } & \multicolumn{2}{|c|}{ Oleic } & \multicolumn{2}{|c|}{ Linoleic } & \multicolumn{2}{|c|}{ Linolenic } & \multicolumn{2}{|c|}{ Eicosadienoic } \\
\hline & S1 & S2 & S1 & S2 & S1 & S2 & S1 & S2 & S1 & S2 & S1 & S2 & S1 & S2 & S1 & S2 \\
\hline $100 \%$ NPK & 0.58 & 0.57 & 1.11 & 1.12 & 12.40 & 12.36 & 3.20 & 3.14 & 22.66 & 22.74 & 49.66 & 51.33 & 0.64 & 0.63 & 2.72 & 2.76 \\
\hline $100 \%$ NPK +humic acid & 0.61 & 0.59 & 1.13 & 1.15 & 12.56 & 12.51 & 3.18 & 3.14 & 22.78 & 22.78 & 49.86 & 51.33 & 0.70 & 0.66 & 2.86 & 2.76 \\
\hline $100 \%$ NPK + bio fertilizer & 0.59 & 0.57 & 1.08 & 1.06 & 12.43 & 12.43 & 3.12 & 3.09 & 22.34 & 22.66 & 49.33 & 50.36 & 0.60 & 0.60 & 2.64 & 2.28 \\
\hline $\begin{array}{l}100 \% \text { NPK + bio fertilizer }+ \\
\text { humic acid }\end{array}$ & 0.64 & 0.63 & 1.17 & 1.22 & 12.68 & 12.59 & 3.26 & 3.18 & 22.98 & 22.86 & 50.06 & 51.66 & 0.78 & 0.66 & 2.98 & 2.86 \\
\hline $75 \%$ NPK & 0.67 & 0.68 & 1.25 & 1.25 & 12.76 & 12.72 & 3.28 & 3.32 & 23.22 & 22.86 & 50.98 & 51.96 & 0.70 & 0.68 & 2.96 & 2.86 \\
\hline $75 \%$ NPK +humic acid & 0.69 & 0.68 & 1.36 & 1.39 & 12.84 & 12.82 & 3.36 & 3.33 & 23.46 & 22.76 & 51.74 & 52.22 & 0.72 & 0.69 & 3.06 & 2.98 \\
\hline $75 \%$ NPK + bio fertilizer & 0.64 & 0.62 & 1.20 & 1.46 & 12.72 & 12.73 & 3.22 & 3.18 & 23.12 & 22.74 & 50.12 & 51.96 & 0.71 & 0.66 & 3.02 & 2.76 \\
\hline $\begin{array}{l}75 \% \text { NPK + bio fertilizer + } \\
\text { humic acid }\end{array}$ & 0.73 & 0.70 & 1.51 & 1.47 & 13.02 & 12.89 & 3.42 & 3.36 & 23.62 & 22.96 & 52.22 & 53.66 & 0.73 & 0.70 & 3.12 & 2.96 \\
\hline $50 \%$ NPK & 0.56 & 0.57 & 1.03 & 1.09 & 12.24 & 12.22 & 2.86 & 2.96 & 21.06 & 22.46 & 48.33 & 49.66 & 0.62 & 0.58 & 2.44 & 2.63 \\
\hline $50 \%$ NPK +humic acid & 0.55 & 0.59 & 1.01 & 1.09 & 12.18 & 12.27 & 2.72 & 3.09 & 22.08 & 22.33 & 48.66 & 50.06 & 0.61 & 0.60 & 2.60 & 2.56 \\
\hline $50 \%$ NPK + bio fertilizer & 0.53 & 0.55 & 0.64 & 0.98 & 12.06 & 12.14 & 2.78 & 2.96 & 21.08 & 22.18 & 47.86 & 49.46 & 0.58 & 0.58 & 2.28 & 2.47 \\
\hline $\begin{array}{l}50 \% \text { NPK + bio fertilizer + } \\
\text { humic acid }\end{array}$ & 0.58 & 0.62 & 1.04 & 1.15 & 12.32 & 12.36 & 2.92 & 3.14 & 21.22 & 22.56 & 48.98 & 50.33 & 0.64 & 0.63 & 2.92 & 2.66 \\
\hline $25 \%$ NPK & 0.60 & 0.54 & 0.87 & 0.86 & 11.98 & 12.06 & 2.68 & 2.76 & 21.74 & 21.96 & 47.33 & 48.33 & 0.48 & 0.54 & 1.98 & 2.28 \\
\hline $25 \%$ NPK +humic & 0.53 & 0.57 & 0.92 & 0.98 & 11.88 & 12.14 & 2.66 & 2.76 & 21.66 & 22.06 & 47.66 & 48.66 & 0.55 & 0.58 & 2.12 & 2.33 \\
\hline $25 \%$ NPK + bio fertilizer & 0.51 & 0.52 & 0.80 & 0.86 & 11.76 & 11.98 & 2.54 & 2.66 & 21.68 & 21.96 & 47.06 & 48.33 & 0.54 & 0.56 & 2.06 & 2.33 \\
\hline $\begin{array}{l}25 \% \text { NPK + bio fertilizer + } \\
\text { humic acid }\end{array}$ & 0.65 & 0.60 & 0.96 & 1.04 & 12.14 & 12.22 & 2.76 & 2.88 & 21.88 & 22.28 & 48.08 & 48.98 & 0.58 & 0.60 & 2.34 & 2.47 \\
\hline F values & 1.1700 & 0.8160 & 2.5700 & 2.0375 & 0.1011 & 0.2495 & 0.2258 & 0.1339 & 0.3995 & 0.0860 & 0.2844 & 0.3007 & 1.4259 & 0.7168 & 0.4247 & 0.1490 \\
\hline LSD 0.05 & 0.1663 & 0.1663 & 0.3287 & 0.3832 & 3.3262 & 4.3409 & 1.7310 & 1.6631 & 3.3262 & 3.3263 & 8.3157 & 8.2572 & 0.1747 & 0.1663 & 1.663 & 1.1663 \\
\hline
\end{tabular}


The present results found in agree with those of Abdel-Moniem and Abd El-Wahab, 2006; Bhagat, 2012 who mentioned that the Medicinal and aromatic plants are afflicted by arthropod pests including aphids. Also, that of Abd El-Wahab, et al 2011 in Egypt, who stated that, the N. sativa plants found infested with Thrips tabaci (Lind.) Oxycarinus hyalinipennis, Emposca descipiens (Padi.), Aphis gossypii (Clova.), Aphis craccivora (Koch.). in added to that of ELEKCİĞLU (2020) who recorded that the N. sativa plants found infested with Frankliniella occidentalis Pergande and Thrips tabaci Lindeman.

\subsubsection{Natural enemies Survey}

The present data in Table (4) clear that, three species of insect predators [lady bird beetle, Coccinella spp.; green lace wing, Chrisoprella carnea (Steph.); hover flies (Syrphus spp.); one predator mites [Phytoseiulus sp.] and one species of aphid parasitoid (Aphidius sp were found associated with pests infested $N$. sativa plants under different chemical, bio and organic fertilizers treatments. The present results found in agree with those of Abdel-Moniem and Abdel-Wahab, (2006) and Abd ElWahab, et al ., (2011) in Egypt, who reported that the N. sativa found infested with certain pests species and associated with certain bio enemies as Deraeocoris sernus (D\&S) Nabis sp. Total hemiptera Syrphus corolla F. Chrysopa vulgaris (Schn) Aphilinus sp. Coccinella undecimpunctata.

\subsection{Effects of tested fertilizers on the dominant pests attacked $N$. sativa plants}

As results in Table (5) show that, the mean numbers of scouted pests by using different sampling methods (as suit sampling for each of its) on $N$. sativa plants were significantly varied $(\mathrm{P} \leq 0.01)$ due to the variation of used bio, organic fertilizers and NPK rates and combination. The relatively low mean numbers of $0.19 \& 1.08$ individual/stroke, $2.22 \& 2.41,0.11 \& 0.33,1.18 \& 0.183$ individual/leaf, 1.11 $\& 2.22$ individual /plant, $1.00 \& 0.78,4.29 \& 2.33$ individuals/sample and $2.22 \& 3.11$ individual/leaf were noticed for the dominant pests, Empoasca decipiens, Aphis gossypii, Bemisia tabaci and Thrips tabaci, Nezara viridula L., Oxycarinus hyalinipenniwere and Helicoverpa armigera on N. sativa plants received Nitrobeen and humic under treatment of $25 \%$ NPK during the two study seasons, respectively. On the other hand the relatively high mean numbers of $5.67 \& 6.33$ individual /stroke, $8.78 \& 10.89$, $3.25 \& 4.55,4.55 \& 4.33$ individual /leaf, 6.67\&5.33, 4.66\&5.67, $20.33 \& 22.33$ individuals /sample and $5.33 \& 18.67$ individual /leaf were recorded for inspected pests on $N$. sativa plants fertilized by $100 \%$ NPK level during the two study seasons, respectively. So, the obtained results cleared that the use of bio (Nitrobee) and organic (humic) fertilizers was enhanced $N$. sativa plants defense against pests attacking.

Generally, the relatively high mean numbers of all inspected pests were associated with high vegetative growth as plant height and branches number which resulted with high quantity and types of nitrogen sources. In the other hand, the relatively lower numbers of pests were recorded in treatments of bio and humic fertilizers under treatment of $25 \%$ NPK during the two study seasons. So, the obtained results cleared that the use of bio (Nitrobeen) and organic (humic acid) fertilizers was enhanced $N$. sativa plants defense against pests attacking. The obtained results found in harmony with those of Chen (2006) who stated that the Excessive uses of chemical fertilizers lead to unexpected environmental effects and sensitivity to pests and diseases by increasing the supply of nitrogen; and that of El-Kordy (1999) who studied population dynamics of aphids infesting medicinal and aromatic plants in Egypt in addition to that of Hashem et al. (2017) who decided that the insect pests are untied to challenge the plant, the integration between organic and bio fetilizers with Tracer or Alkanz will be the most effective ecofriendly strategy to overcome these dramatic conditions to conserve the environment and produce an appreciated yield. Also, with that of Shafique et al., (2016) who noted that, the using of organic additives, phytochemicals and antagonistic microorganisms in controlling pests offers an alternate strategy to the prevalent use of synthetic pesticides. In adding to that of El-Mogy, et al., (2021) who noticed that the organic and bio fertilizers can be used as integrated crop management agent in sustainable agriculture systems to get safe food with relatively low cost upon long run.

\subsection{Effects of tested fertilizers on the predators associated with pests on $\mathbf{N}$. sativa plants :}

The mean numbers of most presence predators tabulated in Table $(6 a, b)$ found associated with pests on N. sativa plants were the three predators species, Syrphus spp., Coccinella spp. and Chrisoprella carnea witch investigated in relatively high mean numbers of $8.7 \& 6.00 ; 5.67 \& 4.33$ and 
Table 5: Survey of piercing-sucking pests and associated natural enemies on $N$. sativa plants fertilized by some bio and organic fertilizers under different levels of chemical fertilization during the two seasons of 2016/2017 and 2017/2018.

\begin{tabular}{|c|c|c|c|c|c|c|}
\hline Groups & English name & Scientific name & Arabic name & Family name & Order name & Occurrence \\
\hline \multirow{11}{*}{ 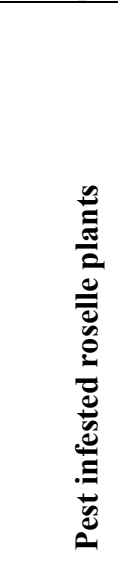 } & leafhopper & Emposca descipiens (Paol.) & el jassid & Cicadellidae & Homoptera & level \\
\hline & \multirow{4}{*}{ Aphids } & Aphis gossypii (Glov.) & \multirow{4}{*}{$\mathrm{Al}$ men } & \multirow{4}{*}{ Aphididae } & \multirow{4}{*}{ Homoptera } & ++++ \\
\hline & & Myzus persicae (sulz) & & & & + \\
\hline & & $\begin{array}{l}\text { Hyadaphis foeniculi } \\
\text { (Passerini) }\end{array}$ & & & & + \\
\hline & & Aphis craccivora (Koch.) & & & & + \\
\hline & \multirow[t]{2}{*}{ Cotton whitefly } & Bemisia tabaci (Genn.) & \multirow{2}{*}{$\begin{array}{l}\text { Zobaba bidaa } \\
\text { cieled }\end{array}$} & Alerodidae & Homoptera & ++ \\
\hline & & Psylla sp. & & Psyllidae & Homoptera & + \\
\hline & Flower thrips & $\begin{array}{l}\text { Frankliniella occidentalis } \\
\text { (Pergande }\end{array}$ & \multirow[b]{2}{*}{ Treps } & \multirow[b]{2}{*}{ Thrpidae } & \multirow[b]{2}{*}{ Thaythanoptera } & + \\
\hline & Onion thrips & $\begin{array}{l}\text { (Pergande } \\
\text { Thrips tabaci (Lin d.) }\end{array}$ & & & & ++ \\
\hline & green stink bug & Nezara viridula $L$ & el buka el hkadraa & pentatomidae & Hemeptera & ++ \\
\hline & cotton seeds bug & $\begin{array}{l}\text { Oxycarenus hyalinipennis } \\
\text { (Costa) }\end{array}$ & $\begin{array}{l}\text { bukt bezret } \\
\text { elcotton }\end{array}$ & Lygaeidae & Hemeptera & ++ \\
\hline \multirow{7}{*}{ 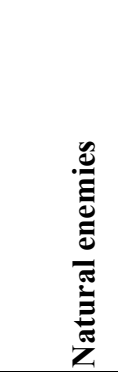 } & Two spotted spider mite & Tetranychus urticea (Koch) & Acaros & Tetranychidae & Acari & ++++ \\
\hline & tomato fruit worm & $\begin{array}{l}\text { Helicoverpa armigera } \\
\text { (Hübner) }\end{array}$ & el amrikiah & Noctuidae & lepidoptera & + \\
\hline & Ladybirds beetles & Coccinella spp. & Abo el eid & Coccinellidae & Coleoptera & ++ \\
\hline & Green lacewing & Chrisoprella carnea (Steph) & Asad al men & Chrysopidae & Neuroptera & ++ \\
\hline & orius bug & orius albidipennis reut. & bukt el oris & anthocoridae & Hemeptera & ++ \\
\hline & Aphids mummies & Aphidius colemani Viereck & Tofiliat al men & Aphidiidae & Hymenoptera & + \\
\hline & Predacious mite & Phytoseiulus sp. & Moftersate acaros & Phytoseiidae & Acari & + \\
\hline
\end{tabular}


Table 6a: Effect of some bio and organic fertilizers under different levels of chemical fertilization on insect species infested $N$. sativa plants during the two seasons of 2016/2017 and 2017/2018.

\begin{tabular}{|c|c|c|c|c|c|c|c|c|}
\hline \multirow{2}{*}{ Treatments } & $1^{\text {st }}$ seasons & $2^{\text {nd }}$ season & $1^{\text {st }}$ seasons & $2^{\text {nd }}$ season & $1^{\text {st }}$ seasons & $2^{\text {nd }}$ season & $1^{\text {st }}$ seasons & $2^{\text {nd }}$ season \\
\hline & \multicolumn{2}{|c|}{ E.decipiens. } & \multicolumn{2}{|c|}{ A. gossypii } & \multicolumn{2}{|c|}{ B. tabaci } & \multicolumn{2}{|c|}{ T. tabaci } \\
\hline $100 \%$ NPK & 5.67 & 6.33 & 8.78 & 10.89 & 3.25 & 4.55 & 4.55 & 4.33 \\
\hline $100 \%$ NPK +humic acid & 4.67 & 5.56 & 7.89 & 10.44 & 3.00 & 4.33 & 3.78 & 3.67 \\
\hline $100 \%$ NPK + bio fertilizer & 3.78 & 5.33 & 7.556 & 10.11 & 2.81 & 4.00 & 3.44 & 3.33 \\
\hline $100 \%$ NPK + bio fertilizer + humic acid & 3.33 & 4.56 & 7.11 & 8.78 & 2.44 & 3.22 & 3.20 & 3.22 \\
\hline $75 \%$ NPK & 2.67 & 4.44 & 6.44 & 8.22 & 2.11 & 2.78 & 3.073 & 2.92 \\
\hline 75\% NPK +humic acid & 2.22 & 3.67 & 6.78 & 7.89 & 2.14 & 2.44 & 2.78 & 2.44 \\
\hline $75 \%$ NPK + bio fertilizer & 2.00 & 3.44 & 5.44 & 7.22 & 2.00 & 2.11 & 2.55 & 2.25 \\
\hline $75 \%$ NPK + bio fertilizer + humic acid & 1.89 & 2.89 & 5.18 & 6.55 & 1.55 & 2.00 & 2.33 & 2.11 \\
\hline $50 \%$ NPK & 1.89 & 2.67 & 5.00 & 6.11 & 1.11 & 1.87 & 2.37 & 1.67 \\
\hline $50 \%$ NPK +humic acid & 1.67 & 2.33 & 4.44 & 5.443 & 0.89 & 1.55 & 2.18 & 1.44 \\
\hline $50 \%$ NPK + bio fertilizer & 0.67 & 2.00 & 4.22 & 5.183 & 0.66 & 1.33 & 2.036 & 1.25 \\
\hline $50 \%$ NPK + bio fertilizer + humic acid & 0.55 & 1.78 & 3.55 & 4.55 & 0.67 & 1.11 & 2.036 & 1.07 \\
\hline $25 \%$ NPK & 0.44 & 1.66 & 3.11 & 4.22 & 0.33 & 1.03 & 1.78 & 1.10 \\
\hline $25 \%$ NPK +humic & 0.33 & 1.33 & 3.18 & 3.44 & 0.25 & 0.78 & 1.44 & 1.00 \\
\hline $25 \%$ NPK + bio fertilizer & 0.19 & 4.82 & 3.03 & 3.03 & 0.11 & 0.33 & 1.25 & 0.44 \\
\hline $25 \%$ NPK + bio fertilizer + humic acid & 0.19 & 1.08 & 2.22 & 2.11 & 0.18 & 0.55 & 1.183 & 0.18 \\
\hline F values & 143.04 & 3.33 & 270.27 & 269.30 & 127.29 & 96.15 & 102.92 & 105.69 \\
\hline LSD $_{0.05}$ & 0.405 & 2.61 & 0.34 & 0.47 & 0.27 & 0.39 & 0.26 & 0.33 \\
\hline
\end{tabular}


Table 6b: Effect of some bio and organic fertilizers under different levels of chemical fertilization on insect species infested $N$. sativa plants during the two seasons of 2016/2017 and 2017/2018.

\begin{tabular}{|c|c|c|c|c|c|c|c|c|}
\hline \multirow{2}{*}{ Treatments } & $1^{\text {st }}$ seasons & $2^{\text {nd }}$ season & $1^{\text {st }}$ seasons & $2^{\text {nd }}$ season & $1^{\text {st }}$ seasons & $2^{\text {nd }}$ season & $1^{\text {st }}$ seasons & $2^{\text {nd }}$ season \\
\hline & \multicolumn{2}{|c|}{ N. viridula } & \multicolumn{2}{|c|}{ H. armigra } & \multicolumn{2}{|c|}{ O. hyalinipennis } & \multicolumn{2}{|c|}{ T. urticae } \\
\hline $100 \%$ NPK & 6.67 & 5.33 & 4.66 & 5.67 & 20.33 & 22.33 & 5.33 & 18.67 \\
\hline $100 \%$ NPK +humic acid & 4.67 & 5.33 & 3.66 & 3.00 & 16.33 & 16.33 & 5.33 & 17 \\
\hline $100 \%$ NPK + bio fertilizer & 5.67 & 6.00 & 2.77 & 2.66 & 15.67 & 14.00 & 6.00 & 15.256 \\
\hline $100 \%$ NPK + bio fertilizer + humic acid & 3.67 & 2.67 & 2.44 & 3.33 & 11.33 & 9.67 & 2.67 & 14.44 \\
\hline $75 \%$ NPK & 4.33 & 5.00 & 2.00 & 2.89 & 10.00 & 8.33 & 5.00 & 13.96 \\
\hline 75\% NPK +humic acid & 3.67 & 2.33 & 2.11 & 2.33 & 9.33 & 8.59 & 2.33 & 12.923 \\
\hline $75 \%$ NPK + bio fertilizer & 2.67 & 1.33 & 2.33 & 2.00 & 8.666 & 8.036 & 1.33 & 12.036 \\
\hline $75 \%$ NPK + bio fertilizer + humic acid & 2.00 & 2.67 & 2.33 & 1.33 & 8.22 & 7.256 & 2.67 & 11.33 \\
\hline $50 \%$ NPK & 5.33 & 4.00 & 1.89 & 1.67 & 7.66 & 6.81 & 4.00 & 10.67 \\
\hline $50 \%$ NPK +humic acid & 3.00 & 3.67 & 1.66 & 1.67 & 7.036 & 6.33 & 3.67 & 10.00 \\
\hline $50 \%$ NPK + bio fertilizer & 2.33 & 3.67 & 1.33 & 1.22 & 6.18 & 5.926 & 3.67 & 9.67 \\
\hline $50 \%$ NPK + bio fertilizer + humic acid & 1.67 & 2.33 & 0.56 & 1.00 & 5.88 & 5.44 & 2.33 & 8.00 \\
\hline $25 \%$ NPK & 1.44 & 2.67 & 2.33 & 1.67 & 5.48 & 4.963 & 2.67 & 6.33 \\
\hline $25 \%$ NPK +humic & 1.33 & 2.33 & 1.33 & 1.33 & 5.036 & 4.443 & 2.33 & 5.37 \\
\hline $25 \%$ NPK + bio fertilizer & 1.33 & 2.27 & 0.78 & 1.11 & 4.55 & 3.81 & 2.22 & 4.443 \\
\hline $25 \%$ NPK + bio fertilizer + humic acid & 1.11 & 2.22 & 1.00 & 0.78 & 4.29 & 2.55 & 2.22 & 3.11 \\
\hline F values & 9.85 & 6.27 & 8.95 & 16.90 & 47.03 & 174.45 & 6.27 & 75.36 \\
\hline $\mathbf{L S D}_{0.05}$ & 1.61 & 1.68 & 1.01 & 0.85 & 1.96 & 1.12 & 1.68 & 1.51 \\
\hline
\end{tabular}


Table 7: Effect of some bio and organic fertilizers under different levels of chemical fertilization on insect predators associated with $N$. sativa plants during the two seasons of 2016/2017 and 2017/2018.

\begin{tabular}{|c|c|c|c|c|c|c|}
\hline \multirow{2}{*}{ Treatments } & $1^{\text {st }}$ seasons & $2^{\text {nd }}$ season & $1^{\text {st }}$ seasons & $2^{\text {nd }}$ season & $1^{\text {st }}$ seasons & $2^{\text {nd }}$ season \\
\hline & \multicolumn{2}{|c|}{ syrphuss } & \multicolumn{2}{|c|}{ Coccinella spp. } & \multicolumn{2}{|c|}{ Chrisoprella carnea } \\
\hline $100 \%$ NPK & 8.67 & 6.00 & 5.67 & 4.33 & 4.33 & 5 \\
\hline $100 \%$ NPK + humic acid & 3.00 & 5.00 & 4.33 & 2.00 & 2.00 & 1.22 \\
\hline $100 \%$ NPK + bio fertilizer & 6.00 & 4.00 & 2.67 & 3.00 & 3.00 & 3.00 \\
\hline $100 \%$ NPK + bio fertilizer + humic acid & 7.00 & 3.67 & 2.33 & 2.67 & 2.67 & 2.33 \\
\hline $75 \%$ NPK & 3.33 & 4.33 & 3.00 & 2.33 & 1.33 & 2.00 \\
\hline 75\% NPK +humic acid & 4.67 & 4.67 & 2.33 & 3.67 & 0.78 & 1.67 \\
\hline $75 \%$ NPK + bio fertilizer & 5.33 & 6.00 & 2.67 & 4.00 & 2.33 & 2.00 \\
\hline $75 \%$ NPK + bio fertilizer + humic acid & 4.00 & 2.67 & 3.00 & 3.33 & 2.33 & 3.67 \\
\hline $50 \%$ NPK & 3.67 & 4.67 & 2.00 & 2.33 & 2.67 & 1.33 \\
\hline $50 \%$ NPK +humic acid & 3.33 & 5.00 & 2.33 & 3.00 & 1.33 & 1.00 \\
\hline $50 \%$ NPK + bio fertilizer & 2.00 & 4.00 & 1.67 & 2.33 & 1.33 & 1.67 \\
\hline $50 \%$ NPK + bio fertilizer + humic acid & 3.33 & 5.33 & 2.00 & 3.00 & 0.78 & 2.00 \\
\hline $25 \%$ NPK & 4.33 & 5.00 & 3.33 & 1.67 & 2.00 & 1.00 \\
\hline $25 \%$ NPK +humic & 4.00 & 5.33 & 2.67 & 2.00 & 1.00 & 0.78 \\
\hline $25 \%$ NPK + bio fertilizer & 3.67 & 2.33 & 1.00 & 2.67 & 2.00 & 2.00 \\
\hline $25 \%$ NPK + bio fertilizer + humic acid & 2.55 & 1.92 & 0.67 & 1.67 & 1.77 & 1.56 \\
\hline F values & 28.12 & 16.71 & 1.87 & 1.84 & 1.15 & 14.07 \\
\hline $\mathbf{L S D}_{0.05}$ & 0.93 & 0.85 & 3.44 & 1.74 & 6.22 & 0.83 \\
\hline
\end{tabular}


$4.33 \& 5.00$ individuals/plant associated with the high numbers of pests infested $N$. sativa plants recorded in treatment of $100 \%$ NPK level during the two study seasons, respectively. While the relatively low mean numbers of $2.00 \& 1.92 ; 0.67 \& 1.67$ and $0.78 \& 0.78$ individuals/plant were recorded on $N$. sativa plants received Nitrobeen and humic fertilizers under treatment of 25 or $50 \%$ NPK during the two study seasons, respectively; in association with low preys numbers of pests individuals,

Generally, the fertilizers treatments were affected the insect predators activity as indirect effect by affecting pests numbers and direct effect by providing good shelter and adults feed for predators. The obtained results found agree with those of Ismail (2001) who stated that, C. carnea, $C$. undecimpunctata, $S$. interrptus, $P$. alfierii and $P$. gallica were the most important insect predaceous species on certain medicinal and aromatic plants.

\section{References}

Abdou, M.A. and A.H. Mahmoud, 2003. . Growth and oil production of Foeniculum vulgare Mill. 2. The effect of number of irrigation and organic fertilizers. J. Agric. Sci. Mansoura, Univ., 28(5): 3868-3888.

Abdel-Moniem, A.S.H., and T.E. Abd El-Wahab, 2006. Insect pests and predators inhabiting roselle plants, Hibiscus sabdariffa L., a medicinal plant in Egypt. Arch. Phytopathol. Pfl. 39(1): 25-32.

Abd El-Wahab, T.E., Ebadah, I.M.A. and Y.A. Mahmoud, 2011. Population Fluctuation of Destructive and Beneficial Insects Inhabiting some Medicinal Plants at Assiut Governorate, Egypt. J. Basic. Appl. Sci. Res., 1(7):554-558,

Abou El-Leel O.F., R.W. Maraei, A.A.A. El-Hamid, 2019. Studying the response of Nigella sativa plants to different fertilizers. Anal. Univ. din Oradea, Fascicula Biologie,. XXVI (1): 14-20

Aiyafar, S., H.M. Poudineh and M. Forouzandeh, 2015. Effect of Humic Acid on Qualitative and Quantitative Characteristics and Essential Oil of Black Cumin (Nigella sativa L.) under Water Deficit Stress. DAV International Journal of Science, 4(2): 89-102

Akhtar, L.H., M. Hussain, R.M. Iqbal, M. Amer, and A.H. Tariq, 2010. . Losses in grain yield caused by Russian wheat aphid Diuraphis noxia (Mordvilko). Sarhad J. Agric., 26(4): 625-628.

Akhani, A., M.T. Darzi, and M.H.S. Hadi, 2012. Effects of Biofertilizer And Plant Density On Yield Components And Seed Yield Of Coriander (Coriandrum Sativum). Inter. J. Agricult. Crop Sci., 4-16:1205-1211.

Akmal, M., S. Freed, M.N. Malik, and H.T. Gul, 2013. Efficacy of Beauveria bassiana (Deuteromycotina: Hypomycetes) against different aphid species under laboratory conditions. Pakistan J. Zool., 45(1): 71-78.

Al-Fraihat, A.H. Al-dalain, S.Y.A., Al-Rawashdeh, Z.B., M.S. Abu-Darwish, and J.A. Al-Tabbal, 2011. Effect of organic and biofertilizers on growth, herb yield and volatile oil of marjoram plant grown in Ajloregion, Jordan. J. Medicinal Plants Res., 5(13): 2822-2833.

Ali, A., and G.M. Aheer, 2007. . Varietal resistanc against sucking insect pests of cotton under Bahawalpur ecological conditions [Pakistan]. J. Agric. Res. Pakistan 45(3): 1-5.

Ali, E.and F. Hassan, 2014. Bio-production of Nigella sativa L. seeds and oil in Taif area. Int. J. Curr. Microbiol. App. Sci., 3(1): 315-328

Ali, M.M.K., M.A. Hasan and M.R. Islam, 2015. Influence of Fertilizer Levels on the Growth and Yield of Black Cumin (Nigella sativa L.). The Agriculturists 13(2): 97-104

Amer, M., M. Aslam, M. Razaq, and M. Afzal, 2009. Lack of plant resistance against aphids, as indicated by their seasonal abundance in canola, Brassica napus (L.) in Southern Punjab, Pakistan. Pakistan J. Bot., 41(3): 1043-1051.

A.O.A.C., 1990. Official Methods of Analysis of the Association of Official Agricultural Chemists (A.O.A.C.) 12th Ed. Washington. D.C.

Badary, O.A., 1999. Thymoquinone attenuates ifosfamide-induced Fanconi syndrome in rats and enhances its antitumor activity in mice. J. Ethnopharmacol., 67: 135-142.

Bhagat, R. C., 2012. Aphids (Insecta) damaging medicinal and aromatic plants of Jammu and Kashmir State (India): an updated checklist and biodiversity. Indian J. Appl. and Pure Biol. 27(1): 1-10.

Black, C.A., D.D. Evans, and L.E. Ensminger, 1965. Methods of soil analysis. Agron. J. Amer. Soc. Agron. Inc. Publ., Madison, Wisconsin, U.S.A. 
Bodlah, I., M. Naeem, and A.U. Mohsin, 2011. Checklist distribution host range and ecology of Aphidoidea (Homoptera) from the rainfed region of Punjab province of Pakistan. Sarhad J. Agric., 27:93-101.

Boraste, A., K.K. Vamsi, A. Jhadav, Y. Khairnar, N. Gupta, S. Trivedi, P. Patil, G. Gupta, M. Gupta, A.K. Mujapara, and B. Joshi, 2009. Biofertilizers: A novel tool for agriculture. International J. of Microbiol. Res., 1(2): 23-31.

Catangui, M.A., E.A. Beckendorf, and W.E. Riedell, 2009. Soybean aphid population dynamics, soybean yield loss, and development of stage- specific economic injury levels. Agron. J. 101(5): 1080-1092.

Chen, J., 2006. The combined use of chemical and organic fertilizers and/or biofetilizer for crop growth and soil fertility. International Workshop on Sustained Management of the Soil-Rhizosphere System for Efficient Crop Production and Fertilizer Use.16-20 October, Thailand.

Dadkhah, A., 2012. Effect of Chemicals and Bio-fertilizers on Yield, Growth Parameters and Essential Oil Contents of Funnel (Foeniculum vulgare Miller.). Journal of Medicinal Plants and Byproducts, 2: 101-105.

Davis, P.H., 1965. Nigella sativa L. In: Flora of Turkey and the East Aegean Islands, Davis, P.H. (Ed.). Edinburgh University Press, Edinburgh, UK., ISBN-13: 9780852245590, pp: 98-105.

Dwivedi, S., S. Shrivastava, D. Dubey, S. Kapoor, and S. Jain, 2007. Status and conservation strategies of herbal oral contraceptives. Planta Indica, 3(1): 5-7.

Egyptian Pharmacopoeia, 1961. General Organization of Governmental Press Affaris.

Elekcioğlu, N.Z., 2020. Thrips species associated with medicinal and aromatic plants in Adana (Turkey) with first record of Bregmatothrips bournieri Pelikan, 1988 (Thysanoptera: Thripidae) Türk. entomol. derg., 44 (2): 177-192.

ELEKCIOĞLU, N. Z., 2020. Thrips species associated with medicinal and aromatic plants in Adana (Turkey) with first record of Bregmatothrips bournieri Pelikan, 1988 (Thysanoptera: Thripidae) Türk. Entomol. Derg., 44 (2): 177-192.

El-Kordy, M. W., A.A. Mohamed, I.A. Marzouk, and H.A. Mohamed, 1999. The changes in population density of aphids attacking some medicinal and aromatic plants in Egypt. J. Agric. Res. 77(1): 195-204.

El-Mogy, E.E.A.M., K.E. Attia, Mona S. Megahed and M.M.A. Ibrahim, 2021. Evaluate productivity and pest resistance in response to the application of organic fertilizers on Hibiscus sabdariffa L. plants Middle East J. Agric. Res., 10(1): 328-343,

Fernandes, D.M., N.T. Doi, R.L. Villas, L.T. Bull, and S.S. Miazaki, 2002. Macronutrients and micro nutrients removal by aerial part of sweet fennel due to liming and chicken manure fertilization. Acta Hort., 569: 185-190.

Gendy, A.S.H., H.A.H. Said-Al Ahl, and A.A. Mahmoud, 2012. Growth, Productivity and Chemical Constituents of Roselle (Hibiscus sabdariffa L.) Plants as Influenced by Cattle Manure and Biofertilizers Treatments. Australian. J. Basic. Appl. Sci., 6(5): 1-12.

Guenther, E., 1961. The Essential Oils, Vol. 1, Van Nostr and Comp. Inc. New York, Phenolic and Phenoic glycosides, p. 357.

Gyaneshwar, P., G. Naresh kumar, L.J. Parikh, and P.S. Poole, 2002. Role of the microorganismes in improving P nutration of plant . Soil. 245: 83-93

Hassan, A.S., M.A. Rafi, H. Javed, A. Zia, M. Naeem, I.A. Khan, and H. Bilal, 2010. Aphidoidea (homoptera) from the northern areas of Pakistan. Sarhad J. Agric., 26(4): 609-611.

Hashem, A.E.A. Hanan, Abeer, E.A. EL-Hadidy and E.A. Ali, 2017. Impact of some safe agricultural treatments on insect pests, vascular wilt disease management and Roselle (Hibiscus sabdariffa L.) productivity under Siwa Oasis condition. Int. J. Environ., 6 (4): 139-162.

Hassan, F.A.S. and E.F. Ali, 2013. A comparative study between traditional mineral nutrition and other alternative sources on anise plant. Europe. J. Sci. Res., 106 (2):201-212.

Hassan, F.A.S., E.F. Ali, and S.A. Mahfouz, 2012. Comparison between different fertilization sources, irrigation frequency and their combinations on the growth and yield of coriander plant. Australian J. Basic. Appl. Sci., 6(3): 600-615.

Hellal, F.A., S.A. Mahfouz, and F.A.S. Hassan, 2011. Partial substitution of mineral nitrogen fertilizer by bio-fertilizer on (Anethum graveolens L.) plant. Agri. Biol. J. North America, 2(4): 652-660. 
Hooks, C.R., and A. Fereres, 2006. . Protecting crops from non-persistently aphid-transmitted viruses: a review on the use of barrier plants as a management tool. Virus Res., 120(1): 1-16.

Ismail, O.M.N., 2001. Studies on some insects attacking aromatic and medicinal plants. M.Sc. Thesis, Fac. Agric., Cairo Univ., Egypt.

Jackson, M.L., 1978. Soil Chemical Analysis. Fall Indian Private. Ltd. New Delhi.

Jhaa, P., M. Ramb, M.A. Khanb, U. Kiranb, and M.Z. Mahmooduzzafara, 2011. Impact of organic manure and chemical fertilizers on artemisinin content and yield in Artemisia annua L. Industrial Crops and Products. 33: 296301

Katkat, A.V., H. Çelik, M.A. Turan and B.B. Asik, 2009. Effects of soil and foliar applications of humic substances on dry weight and mineral nutrients uptake of wheat under calcareous soil conditions. Aust. J. Basic \& Appl. Sci., 3(2): 1266-1273

Khalid A.K. and M.R. Shedeed, 2015. Effect of NPK and foliar nutrition on growth, yield and chemical constituents in Nigella sativa L. J. Mater. Environ. Sci., 6 (6): 1709-1714

Leung, A.Y. and S. Foster, 1996. Encyclopedia of Common Natural Ingredients used in Foods, Drugs and Cosmetics. 2nd Edn., John Willy and Sons, New York, ISBN-13: 9780471508267, 649.

Little, T.M. and F.J. Hills, 1975. Statistical methods in agricultural research available from U.C.D. Book store, University of California, Davis: 241.

Mohammad, M., I.D. Ebrahim, N.R. Houshang, and T. Ahmad, 2013. Growth and yield of tomato (Lycopersicon esculentum Mill.) as influenced by different organic fertilizers. International Journal of Agronomy and Plant Production, 4: 734-738.

Mousa, G.T., M.M. Gad, G.A. Ahmed and S.A. Mohamed, 2012. Comparative Study on Black Cumin (Nigella sativa, L.) Plants, Grown Under Different Plant Spacing and Fertilization treatments Assiut J. Agric. Sci., 43:(6)(56-70)

Rasmussen, S., A.J. Parsons, A. Popay, H. Xue, and J.A. Newman, 2008. . Plant-endophyte-herbivore interactions: More than just alkaloids? Plant Signal. Behave. 3(11): 974-977.

Sayed, A.V., and A.F. Hossein, 2011. Investigation of biofertilizers influence on quantity and quality characteristics in Nigella sativa L. J. Horticulture For., 3(3):88-92.

Shafique, H.A., V. Sultan, S. Ehteshamul-Haque and M. Ather, 2016. Management of soil-borne diseases of organic vegetables. Journal of Plant production Research, 1. 56 (3): 222- 230.

Shaalan, M.N., 2005. Influence of biofertilization and chicken manure on growth, yield and seeds quality of Nigella sativa, L. plants. Egypt, J. Agric. Res., 83(2): 811-828.

Singh, S.R., 2004. Effect of organic farming system on yield and quality of brinjal (Solanum melongena, L.) under mid-hill conditions of Himachal Pradesh. Haryana Journal of Horticulture Sciences. Horticultural Society of Haryana, Hisar, India, 33 (3): 265-266.

Sokhangoy, S.H., K.D. Ansari, and E. Asli, 2012. 'Effect of bio-fertilizers on performance of dill (Anethum graveolens). Iranian. J. Plant Physiol., 2 (4): 547-552.

Ustun, G., L. Kent, N. Cekin and H. Civelekoglu, 1990. Investigation of the technological properties of Nigella sativa, L. (black cumin) seed oil. JAOCS, 67 (12): 71-86.

Valadabadi, S.A. and H.A. Farahani, 2013. Influence of biofertilizer on essential oil, harvest index and productivity effort of black cumin (Nigella sativa L.). Inter. J. Biotechnol. Mole. Biol.Res., $4(2): 24-27$.

Zhou, Y. and A. Luo, 2004. Effect of organic manure on the quality of vegetables in plastic-sheetcoverd sheds. Acta Agriculturae Zhejiangensis. Zhejiang Academy of Agricultural. Sciences, Hangzhou, China, 16(4): 210-212. 